\title{
Ouabain Modulates the Distribution of Connexin 43 in Epithelial Cells
}

\author{
Arturo Ponce Isabel Larre Aida Castillo Catalina Flores-Maldonado \\ Odette Verdejo-Torres Ruben Gerardo Contreras Marcelino Cereijido
}

Department of Physiology, Biophysics and Neurosciences, Center for Research and Advanced Studies (Cinvestav), México D. F., México

\section{Key Words}

Ouabain • Cnx43 • Gap junctions • MDCK cells • c-SrC and ERK1/2

\begin{abstract}
Background/Aims: The fact that ouabain has been identified as an endogenous substance, led us to inquire its physiological role in epithelial cells. Based on previous observations, we hypothesized that it influences processes related to cell contacts. Previously we have shown that nanomolar concentrations of ouabain up-regulate tight junctions, accelerate ciliogenesis, and increase gap junctional intercellular communication (GJIC). Given that silencing assays indicated that connexin $43(\mathrm{Cnx} 43)$ is involved in the GJIC response, in the present work we study whether ouabain affects $\mathrm{Cn} \times 43$ expression and distribution. Methods: We seeded confluent monolayers of epithelial renal MDCK cells and incubated them with $10 \mathrm{nM}$ ouabain during $1 \mathrm{~h}$. Then we measured, by densitometric analysis of Western blot assays, the amount of $\mathrm{Cnx43}$ in cells and in fractions enriched of plasma membrane. We also studied its localization with immunofluorescence and confocal microscopy. Results: Cnx43 is remarkably displayed, outlining the borders of cells gathered in clusters, randomly scattered throughout the monolayer. Ouabain increases the density of such clusters, as well as the average number of cells per cluster, without inducing the synthesis of new $\mathrm{Cnx}$ 43. It also promotes relocation towards the membrane, of subunits already available. The fact that such changes are inhibited by PP2 and PD98059 indicates that a signaling pathway, that includes C-Src and ERK1/2, is involved in this response. Conclusion: Ouabain induces the translocation of $\mathrm{Cnx} 43$ from the cytoplasm to the plasma membrane. These findings support our hypothesis that one of the physiological roles of ouabain is the modulation of physiological processes that depend on cell to cell contacts.

(C) 2016 The Author(s)

Published by S. Karger AG, Basel
\end{abstract}

\section{Introduction}

Ouabain is a highly toxic compound of remarkable interest on cellular physiology and medicine. Originally obtained from Acokanthera ouabaio and Strophanthus gratus, both A. Ponce and I. Larre shared first authorship. 


\section{Cellular Physiology Cell Physiol Biochem 2016;39:1329-1338 \\ \begin{tabular}{ll|l} 
DOI: 10.1159/000447837 & $\begin{array}{l}\text { O 2016 The Author(s). Published by S. Karger AG, Basel } \\
\text { wwww.karger.com/cpb }\end{array}$ \\
and Biochemistry & Published online: September 08, 2016
\end{tabular} \\ Ponce et al.: Ouabain Induces Relocation of $\mathrm{Cnx} 43$}

plants native to eastern Africa, it was traditionally used as an arrow poison for hunting and warfare [1]. Also known as g-strophanthin, ouabain belongs to a group of compounds known as cardiotonic steroids, because of its chemical structure, and its influence on heart function. When administered at toxic dosages it produces heart failure and death, nonetheless, at controlled dosages has been used therapeutically to treat heart arrhythmias and hypotension $[2,3]$. A substance identical to the plant-derived ouabain was reported to be endogenously present in the plasma of some mammalian species, including humans [4]. Further studies have shown endogenous ouabain to be produced in the adrenal cortex and hypothalamus [5, $6]$. These findings have led to regard ouabain as a hormone $[7,8]$, whose physiological role is still not fully understood.

Ouabain binds to the $\mathrm{Na}^{+} / \mathrm{K}^{+}$-ATPase, blocking its pumping function. This leads to an increase of intracellular sodium, which in turn reduces the activity of the $\mathrm{Na}^{+} / \mathrm{Ca}^{2+}$ exchanger, producing an increase of intracellular calcium. This scheme accounts for the effect of ouabain on the heart because it results in higher cardiac contractility and an increase in cardiac vagal tone $[9,10]$. Recently it has been found that $\mathrm{Na}+\mathrm{K}+-\mathrm{ATPase}$ also acts as a receptor of ouabain $[11,12]$. Binding of ouabain to $\mathrm{Na}+\mathrm{K}+-\mathrm{ATPase}$ unleash a cascade of interrelated signal transduction pathways that involves inositol $(3,4,5)$-tris-phosphate receptor, Src kinase, tyrosine phosphorylation, epidermal growth factor receptor, Ras and the Ras/Raf/MEK/MAPK signaling pathway [13-15]. Following this scheme, ouabain has shown to influence a wide variety of physiological processes, including proliferation [16, 17], growth [18], apoptosis [19-21] and cell mobility [22] in different tissues and organs. It also has been shown to influence the regulation of salt-sensitive blood pressure [23], salt handling in the kidney [24], vascular tone, $\mathrm{Na}^{+}$homeostasis [25] and embryonic kidney cell's survival during malnutrition [26].

We have studied the effect that ouabain, in a nanomolar dose $(10 \mathrm{nM})$, has on the physiology of epithelial cells. Using MDCK epithelial cells as a model, we have shown that it influences several processes related to cell-cell contact [27]: (1) The hermeticity and the molecular composition of tight junctions [28], a fundamental component of epithelial transporting phenotype [29]; (2) It accelerates ciliogenesis, a feature requiring close cell-cell contacts and that is a visible sign of polarity [30]. More recently we have focused on its effect on Gap Junctional Intercellular Communication (GJIC).

Gap junctions are molecular assemblies between neighboring cells, which by this mean exchange small molecules, such as ions, second messengers and metabolites [31, 32]. Gap junctions are found in cells of almost every organ and tissue, but are particularly abundant in tissues where a coordinated response is required, as for instance in cardiac and smooth muscle or in endocrine glands. Gap junctions are displayed as plate-shaped structures between cells. Such plates are clusters of intercellular channels, formed by head-to-head docking of two hemichannels or connections, contributed by each of two neighboring cells. Connexons are in turn formed by six tetraspan membrane proteins known as connexins (Cnx) $[33,34]$. There exist a variety of distinct types of connexins, which are differentially expressed among tissues of vertebrate species to form homomeric or heteromeric connexons. The human genome contains 21 connexin isoforms, whereas the mouse has 20 [35]. Connexins are named by its molecular weight, for instance $\mathrm{Cnx} 32$ represents the connexin protein of $32 \mathrm{kDa}$. From among the different types $\mathrm{Cnx} 43$ is of striking interest because it is one of the most abundantly expressed in a variety of organs and tissues in mammals, besides that its expression has been described to be related to a variety of cellular processes such as cellular proliferation and apoptosis [36-39].

To date little is known about the effect of ouabain on GJIC. It has been reported that 100 $\mu \mathrm{M}$ ouabain produces no effect on GJIC of primary cultures of rat Sertoli cells and cardiac myocytes [40], whereas it caused a significant degree of junctional uncoupling in isolated rabbit corneal endothelium [41]. Ouabain (1 $\mathrm{mM})$ has been shown to inhibit GJIC in rat aortic A7r5 smooth muscle cells, monkey COS-1 fibroblasts and human HeLa epithelial cells [42]. An effect that has been shown to depend on localized changes in $\left[\mathrm{Ca}^{2+}\right.$ (i) through modulation of $\mathrm{Na}^{+} / \mathrm{Ca}^{2+}$-exchanger activity [43]. 


\section{Cellular Physiology Cell Physiol Biochem 2016;39:1329-1338

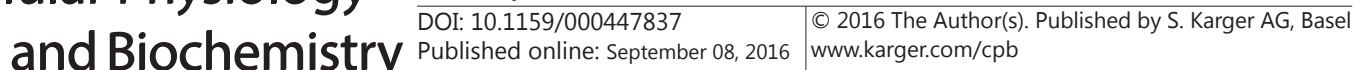 \\ Ponce et al.: Ouabain Induces Relocation of $\mathrm{Cnx} 43$}

In a previous work we showed, by dye transfer assays and electrical capacitance measurements, that ouabain $10 \mathrm{nM}$ enhances GJIC up to $475 \%$ within 1 hour in MDCK cells [44]. The fact that such response occurs quickly (after 10 minutes of addition of ouabain), and that it is not affected by cycloheximide or Actinomycin D suggest that ouabain does not induce the synthesis of new connexins in order to enhance GJIC but rather promotes the relocation of subunits already synthesized. Using silencing assays, we also demonstrate that this ouabain-induced enhancement of GJC involves Cnx43.

Therefore, in the present work we resorted to immunohistochemical methods to elucidate how ouabain influences the expression and distribution of $\mathrm{Cnx} 43$.

\section{Materials and Methods}

\section{Cell culture}

Starter MDCK-II cell cultures (Canine renal; American Type Culture Collection, CCL-34). The cells were grown at $36.5^{\circ} \mathrm{C}$ in a $5 \% \mathrm{CO}_{2}$ atmosphere in Dulbecco's modified Eagle medium (DMEM; life technologies, Carlsbad, CA, USA) supplemented with penicillin-streptomycin 10,000 U/ $\mu \mathrm{g} / \mathrm{ml}$ (In Vitro, Acayucan, México) and 10\% fetal bovine serum (GIBCO). This medium referred to as CDMEM. The cells were harvested with trypsin-EDTA (In Vitro) and seeded on glass coverslips placed at 24-well multi-dishes (3524; Costar Corning, NY, USA) for immunofluorescence and Western blot analysis.

\section{Ouabain challenge protocol}

Cells were cultured at a saturating density of $\sim 70 \%$ and maintained for one day in CDMEM, then kept for $24 \mathrm{~h}$ in DMEM containing 1\% fetal bovine serum before treatment with or without $10 \mathrm{nM}$ ouabain (0-3125; Sigma-Aldrich, St Louis MO, USA). For signaling studies, monolayers were exposed to either 25 $\mu$ M PD98059 (513000; Merck Millipore, Darmstadt GE), an inhibitor of MEK1/2 kinase that impairs the activation of the Extracellular Regulated Kinase 1/2 (ERK1/2), or $10 \mu$ M PP2 (529573; Merck Millipore), an inhibitor of c-Src kinase. In both cases, those inhibitors were added $1 \mathrm{~h}$ before ouabain challenge.

\section{Immunofluorescence}

Monolayers on coverslips were washed three times with ice-cold PBS containing $\mathrm{Ca}^{2+}$, fixed and permeabilized with methanol for $8 \mathrm{~min}$ at $-20^{\circ} \mathrm{C}$, washed three times with PBS, blocked for $1 \mathrm{~h}$ with $0.5 \%$ bovine serum albumin and incubated overnight at $4^{\circ} \mathrm{C}$ with rabbit anti-Cnx43 antibody (71-0700; Invitrogen) or mouse anti- $\alpha 1-\mathrm{Na}^{+} / \mathrm{K}^{+}$-ATPase (MA-3-929; Thermo Fisher Scientific, Waltham, MA, USA). The samples were washed, incubated with secondary antibody (goat anti-rabbit-FITC, 65-6111, Thermo Fisher Scientific), or goat-anti-mouse-TRICT (115-123003; Jackson Immunoresearch, PA, USA), rinsed, incubated with $1 \mu \mathrm{g} / \mathrm{ml}$ DAPI (Sigma-Aldrich, St Luis, MO, USA) in PBS for five minutes, mounted in vectashield (H1000; Vector Laboratories, Burlingame, CA, USA), and examined by confocal microscopy (SP8, equipped with Plan-NeoFluar 63x NA 1.4 objective, Leica Microsystems, Wetzlar, Ger). Sampled images were analyzed with the software Las AF (Leica) and FIJI (FIJI is Just Image J), imported into GIMP (GNU is not Unix Image Manipulation Program) to adjust brightness and contrast and to construct Figures.

Immunoblot

Cell monolayers were washed three times with ice-cold PBS with $\mathrm{Ca}^{2+}$ and then incubated at $4 \stackrel{\circ}{\circ} \mathrm{C}$ for 10 min with lysis buffer (24948; Santa Cruz catalog, CA, USA), supplemented with a protease inhibitor cocktail (Complete $^{\mathrm{TM}}$ 469311600; Sigma-Aldrich), for protein extraction. These protein extracts were then centrifuged for $10 \mathrm{~min}$ at 17,000 $\mathrm{g}$ and the supernatant recovered to measure total protein content with the Micro BCA ${ }^{\mathrm{TM}}$ assay (23235; Thermo Fisher Scientific). An equal volume of $2 \mathrm{x}$ Laemmli sample buffer (1610737; Bio-Rad, Hercules, CA, USA) was then added to the protein extracts, that were subsequently resolved by SDS-polyacrylamide gel electrophoresis (PAGE), and transferred to PVDF sheets (Hybond-P, SigmaArdrichJ) with the help of a Transblot Turbo (Bio-Rad), following the instructions of the manufacturer. These sheets were blocked for 10 min with $0.05 \%$ bovine serum albumin in Tris Buffer Saline (TBS, 10 $\mathrm{mM}$ Tris- $\mathrm{HCl}, 100 \mathrm{mM} \mathrm{NaCl}$ ) supplemented with $0.1 \%$ Tween-20 (TBS-T), incubated with a rabbit-antiCnx43 antibody in TBS-T, supplemented with BSA $0.5 \%$, for $20 \mathrm{~min}$ at room temperature, washed with 


\section{Cellular Physiology Cell Physiol Biochem 2016;39:1329-1338 \begin{tabular}{l|l|l|l|l}
\hline DOI: 10.1159/000447837 & $\begin{array}{l}\text { C } 2016 \text { The Author(s). Published by S. Karger AG, Basel } \\
\text { www.karger.com/cpb }\end{array}$
\end{tabular} \\ Ponce et al.: Ouabain Induces Relocation of $\mathrm{Cnx} 43$}

TBS-T and then incubated with a HRP-goat-anti-rabbit (G-21234; Sigma-Aldrich). The blotting procedure was performed with the help of a SNAP id 1.0 (Millipore, Billerica, MA, USA) following the instructions provided by the manufacturer. Bands were resolved by chemiluminescence (RPN2232 ELC, GE Healthcare Life Sciences, Malborough, MA, USA) using Hyperfilm (GE Healthcare Life Sciences). Then membranes were stripped by incubation (30 min at $37{ }^{\circ} \mathrm{C}$ with gentle shaking) in 3\% sodium hydrosulfite (157953; SigmaAldrich) in TBS-T, and incubated with mouse anti-actin (a kind gift from Dr. José Manuel Hernández from the Department of Cell Biology, Cinvestav) or rabbit-anti-gp135 (a generous gift from Raya A., Department of Physiology, Cinvestav, México City), depending on the experiment, and processed as described above. Densitometric analysis was performed with Kodak 1D 3.5.4 software (Eastman Kodak, Rochester, NY, USA). Cnx43 densitometric measurements were related to those from actin or gp135. For the purpose of comparison, the corrected optical density of monolayers under control condition was arbitrarily standardized with a value of 1 .

\section{Plasma membrane protein extraction}

Plasma membrane proteins were extracted using a kit obtained from Abcam (Plasma membrane extraction kit ab65400, Abcam, Cambridge, UK). Briefly: all procedures were developed at $4^{\circ} \mathrm{C}$. Monolayers were scraped from $100 \mathrm{~mm}$ Petri dishes (four for each condition), resuspended in $8 \mathrm{ml}$ of PBS, then centrifuged (1057 g, $5 \mathrm{~min}$ ). Precipitates were re-suspended in $2 \mathrm{ml}$ of lysis buffer (provided by the manufacturer), then homogenized with 150 strokes in a Dounce Homogenizer (cat. D8938, Sigma-Aldrich) with ice and centrifuged at $700 \mathrm{~g}$ for $10 \mathrm{~min}$ at $4^{\circ} \mathrm{C}$. The supernatant was then centrifuged in a new vial for $30 \mathrm{~min}$ at $10000 \mathrm{~g}$ and the precipitate was further processed to perform a step gradient plasma membrane extraction. The precipitate is resuspended in an upper phase solution (provided by the manufacturer) and an equal volume of the lower phase solution of higher density (provided by the manufacturer) is then added. After gently shaken, the extract is centrifuged $1000 \mathrm{~g}$ for $5 \mathrm{~min}$, the superior phase is recovered and the remaining lower phase is mixed again with an upper phase solution to repeat the extraction. Both superior phases are combined and the step gradient plasma membrane extraction repeated once more. The final upper phase was diluted with 5 volumes of water and centrifuged at 17,000 g for $10 \mathrm{~min}$. The pellet is re-suspended in TX-100 $0.1 \%$ in water. These plasma membrane extracts were then processed by immunoblot.

\section{Analysis of $\mathrm{Cnx} 43$ and $\mathrm{Na}^{+} / \mathrm{K}^{+}$-ATPase colocalization}

To estimate the co-localization of $\mathrm{Cnx} 43$ with the $\mathrm{Na}^{+} / \mathrm{K}^{+}$-ATPase of the plasma membrane, we used the LAS-AF software (v 2.3.0, Leica). We first captured 10 images for monolayers cultured 1 hour in control conditions or with $10 \mathrm{nM}$ ouabain. Then we selected a region of interest in each image, choosing the membrane labeling, identified by the "chicken fence" like pattern, and avoiding the cytoplasmic label as much as possible. The signals of both channels were overlaid to reveal co-localized pixels. We then set the threshold (30\%) and background (20\%) level, based on the "Red-Green" or "Red-blue" scattergram offered by the LAS-AF software (Leica). The co-localization rate (\%) was calculated with the same image analysis software (Leica, \% co-localization rate $=$ co-localization area/area foreground; area foreground = area image - area background). The average of data obtained from 10 images was considered a value of a single independent experiment.

\section{Statistical analyses}

Statistical analyses were performed using Prism 5 (GraphPad software). The results are expressed as the means \pm standard error. Statistical significance was estimated via one-way analysis of variance (ANOVA) followed by Bonferroni's multiple comparison or Student's t-test and was denoted as follows: ${ }^{*} P<0.05,{ }^{* *}$ $P<0.005$ and ${ }^{* * *} P<0.001$ and $n$ is the number of independent experiments.

\section{Results}

Ouabain does not promote synthesis of Cnx43

Our previous findings, that $10 \mathrm{nM}$ ouabain triggers a quick enhancement of GJIC, plus the fact that this response is not impaired by inhibitors of RNA or protein synthesis [44] suggest that no synthesis of connexins are required to achieve this effect. To test this 


\section{Cellular Physiology Cell Physiol Biochem 2016;39:1329-1338

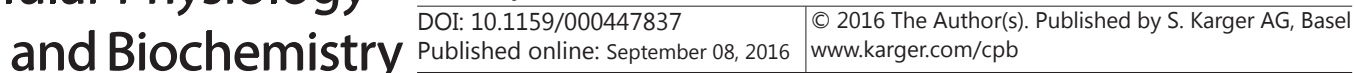 \\ Ponce et al.: Ouabain Induces Relocation of $\mathrm{Cnx43}$}

Fig. 1. Ouabain does not increase the expression level of Cnx43. (A) Cell lysates were prepared from MDCK monolayers, either control or incubated with $10 \mathrm{nM}$ ouabain for 1 hour, then equal amounts of total cell protein were subjected to SDS-PAGE and western blotting with antiCnx43 antibodies. In both cases a multi-band pattern was obtained. The blots were then stripped and re-probed with anti-actin antibodies. (B) The $\mathrm{Cnx} 43$ signal density of gels, as shown in (A), was measured and normalized with to actin label. The statistical analysis shows nonsignificant difference between control and treatment. " $n$ " stands for the number of assays analysed.

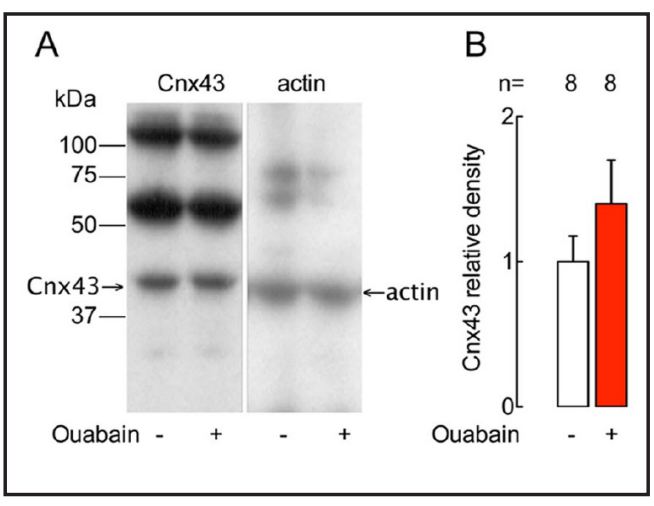

Fig. 2. Ouabain changes the distribution pattern of $\mathrm{Cnx} 43$. (A, B) Representative images showing the pattern of distribution of Cnx43 in MDCK monolayers, under (A) control conditions, or (B) after one hour incubation with $10 \mathrm{nM}$ ouabain. (A) Under control conditions, many cells express Cnx43 signal (green) as a faint borderline, suggesting basolateral localization (white arrowheads), although intracellular staining is also observed (yellow arrows). Clusters of cells expressing a more intense Cnx43signal are clearly noticed (red arrow). (B) Ouabain in-
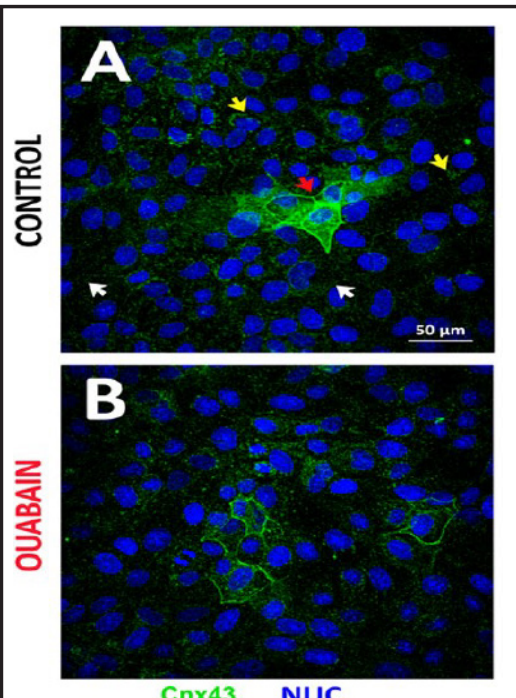

Cnx43 NUC
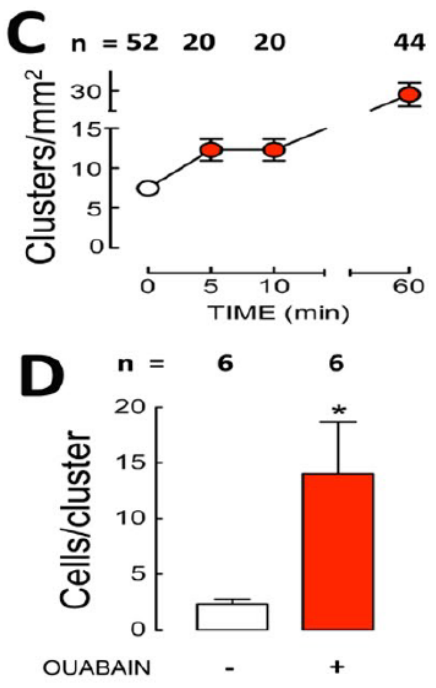
creases the density of these clusters, as well as the number of cells that form them. (C) Statistical analysis of the density of the clusters of cells expressing $\mathrm{Cnx} 43$, as a function of time, after ouabain challenge. The error bar in the 0 time point is smaller that the symbol. (D) Comparison of the number of cells per group in control and ouabain-treated monolayers. $\left(^{*}\right)$ indicates a statistically significant difference $(p<0.05)$ between control and treatment groups. "n" stands for the number of images observed.

hypothesis, we compared, by densitometry analysis of Western blots, the protein level of Cnx43 from total protein extracts obtained from MDCK monolayers, without (control) and after 1 hour of treatment with $10 \mathrm{nM}$ ouabain. Figure 1A shows representative blots of both cases. The two of them exhibit a typical pattern, consisting in several bands, due to distinct phosphorylated states [45-48]. Figure 1B shows the corresponding statistical analysis of densitometric measurements, normalized with actin. The fact that no significant difference in the density of control and treatment batches supports further the hypothesis that ouabain per se does not increase the expression level of $\mathrm{Cnx} 43$, at least within one hour of treatment.

Ouabain induces changes in the pattern of distribution of Cnx43

Next, we investigated whether ouabain enhances GJIC by promoting changes in the distribution of $\mathrm{Cnx} 43$. Figure 2 shows the pattern exhibited by $\mathrm{Cnx} 43$ in the absence (control, $2 \mathrm{~A}$ ) and in the presence of $10 \mathrm{nM}$ ouabain (Fig. 2B). In the former case, Cnx43 is expressed all over the monolayer, where cells tend to express $\mathrm{Cnx} 43$ as a faint chicken fence-like pattern, characteristic of a basolateral distribution (white arrows), although abundant intracellular staining is also observed (yellow arrows). It is strikingly noticeable the presence of clusters of cells, randomly scattered throughout the monolayer, where $\mathrm{Cnx} 43$ is more intensely expressed (red arrow). Treatment with $10 \mathrm{nM}$ ouabain produces an increase in the density of 


\section{Cellular Physiology Cell Physiol Biochem 2016;39:1329-1338 \begin{tabular}{ll|l} 
DOI: 10.1159/000447837 & $\begin{array}{l}\text { O 2016 The Author(s). Published by S. Karger AG, Basel } \\
\text { mwwhkargercom/cpb }\end{array}$
\end{tabular} \\ Ponce et al.: Ouabain Induces Relocation of $\mathrm{Cn} \times 43$}

Fig. 3. Ouabain increases the colocalization of Cnx43 with $\alpha-\mathrm{Na}^{+} / \mathrm{K}^{+}$-ATPase. Monolayers costained with antibodies against $\mathrm{Cnx} 43$ (green) and $\alpha-\mathrm{Na}^{+} / \mathrm{K}^{+}$-ATPase (red) cultured in control conditions (A) and with $10 \mathrm{nM}$ ouabain added to the media for 1 hour (B). (C) Percentage of colocalization rate in images obtained from monolayers cultured in control (white bar) and $10 \mathrm{nM}$ ouabain (red bar). ( ${ }^{* *}$ ) indicates a statistically significant difference $(\mathrm{p}<0.005)$ between control and treatment groups. " $n$ " stands for the number of images analyzed.

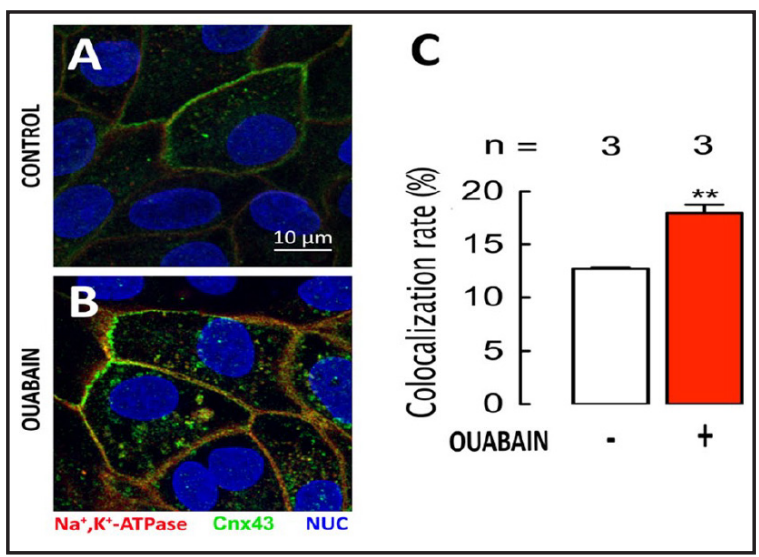

Fig. 4. Ouabain increases $\mathrm{Cnx}-43$ in plasma membrane. Protein extracts from plasma membranes were obtained from MDCK monolayers, either under control or 1 hour of $10 \mathrm{nM}$ ouabain treatment, After SDS-PAGE, immunoblots were made to reveal $\mathrm{Cnx} 43$. (A) representative immunoblots. (B) densitometric analysis. $\left.{ }^{* *}\right)$ indicates a statistically significant difference $(\mathrm{p}<0.005)$ between control and treatment groups. " $n$ " stands for the number of blots analyzed.

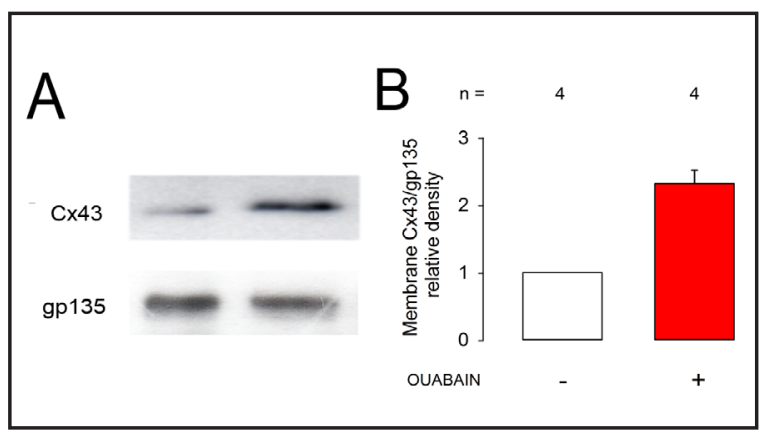

Fig. 5. Ouabain induces membrane relocation of Cnx43 through the activation of c-Src and ERK1/2. (A) (Above) Representative examples of western blot assays (Below) statistical analyses of the comparison of relative density of $\mathrm{Cnx} 43 / \mathrm{gp} 135$ labels under control (white bar), ouabain (red bar) and ouabain plus PP2 (blue bar) treatments. The $\left(^{*}\right)$ and $\left(^{* *}\right)$ signs indicate a statistically significant difference between the bars that indicate the horizontal lines. " $n$ " stands for the number of assays. (B) Bars indicate de average ( \pm S.E.) of the density of clusters of monolayers under control

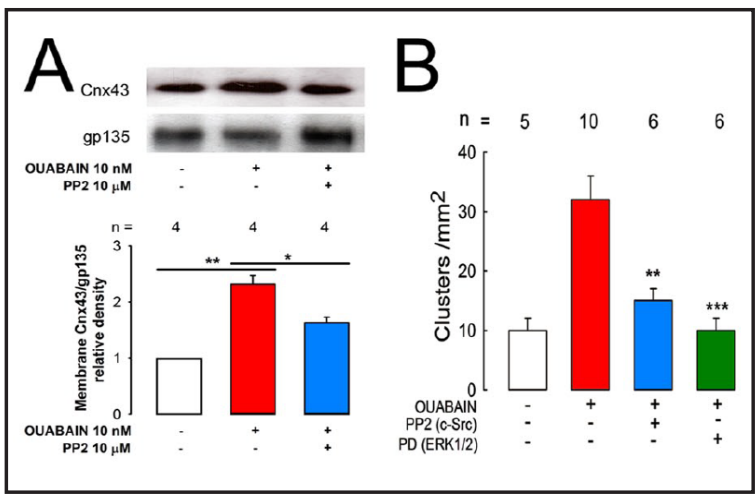
(white bar), as well as from: monolayers treated with $10 \mathrm{nM}$ ouabain (red bar); monolayers pre-treated with PP2, then ouabain (blue bar) and monolayers pretreated with PD98059 before adding ouabain for 1 $\mathrm{h}$ (green bar). Statistical significance was estimated via one-way analysis of variance (ANOVA) followed by Bonferroni's multiple comparison or Student's t-test. ( ${ }^{* *}$ ) denotes $P<0.005$ and (***) $P<0.001$. "n" stands for the number of images analyzed.

those clusters of cells (Fig. 2C) which is significant from as early as 5 minutes after addition of ouabain $10 \mathrm{nM}$ to external media. Ouabain also causes a significant increase of the average number of cells per cluster (Fig. 2D).

Ouabain promotes relocation of Cnx43 to the membrane.

We noticed that the $\mathrm{Cnx} 43$ borderline pattern exhibited by cells, within clusters of monolayers treated with ouabain, appears more intense and delineated as compared to those from untreated monolayers. This suggests that ouabain promotes recruitment of $\mathrm{Cnx} 43$ subunits towards the basolateral membrane. To test such possibility, we estimated how close Cnx43 co-localizes with $\mathrm{Na}^{+} / \mathrm{K}^{+}$-ATPase, which was taken as a basolateral membrane marker. Figure 3 shows two representative images of the co-staining of $\mathrm{Na}^{+} / \mathrm{K}^{+}$-ATPase (red) and Cnx43 (green) in a control monolayer (Fig. 3A), and in a monolayer treated for $1 \mathrm{~h}$ with 10 


\section{Cellular Physiology Cell Physiol Biochem 2016;39:1329-1338 \\ \begin{tabular}{l|l|l} 
and Biochemistry Published online: September 08, 2016 & $\begin{array}{l}\text { (c) 2016 The Author(s). Published by S. Karger AG, Basel } \\
\text { www.karger.com/cpb }\end{array}$ \\
\hline
\end{tabular} \\ Ponce et al.: Ouabain Induces Relocation of $\mathrm{Cnx43}$}

nM ouabain (Fig. 3B). Figure 3C shows the corresponding statistical analysis, indicating that in fact $10 \mathrm{nM}$ ouabain promotes a significant displacement of $\mathrm{Cnx} 43$ towards the membrane. To further support this conclusion, we made Western blots assays from plasma membrane extracts obtained from MDCK monolayers (Fig. 4). A statistically significant difference in the protein density of $\mathrm{Cnx} 43$ between samples under control and treatment with 1 hour incubation of $10 \mathrm{nM}$ ouabain was obtained. This difference was not observed, in contrast, on the density of gp135, a membrane protein that was therefore taken as standard. These results may be taken as further indication that $\mathrm{Cnx} 43$ is relocated to the plasma membrane.

Ouabain-promoted Cnx43 recruitment is regulated by a signaling route involving c-Src and $E R K 1 / 2$

Extracellular Regulated Kinases 1 and 2 (or ERK1/2) are two related extracellular signal-regulated kinases that participate in the Ras-Raf-MEK-ERK signal transduction cascade. It is known that this cascade participates in the regulation of a large variety of processes that includes cell adhesion [48]. On the other hand, c-Src is a tyrosine kinase that is mutated in several cancers. We have previously found that ouabain mediates its effect on GJIC by a signal transduction cascade that includes c-Src and ERK1/2 [44]. To determine whether such signal transduction cascade is also involved in the relocation of $\mathrm{Cnx} 43$ induced by ouabain, we probed whether commercial inhibitors of c-SRC or ERK1/2 impairs any of the effects caused by ouabain, either the increase of $\mathrm{Cnx} 43$ protein density from Western blot assays of membrane extracts, or the increase of the density of clusters of cells observed in immunohistochemical assays. Figure 5A shows representative stains (above) and the statistical analysis that compares the densitometry analyses of Western blot assays made with membrane extracts of MDCK cells under control (white bar), treatment with $10 \mathrm{nM}$ ouabain (red bar) and ouabain plus $10 \mu \mathrm{M}$ PP2 (an inhibitor of c-Src kinase, blue bar). As shown previously, ouabain increased significantly $(\mathrm{p}<0.005)$ the relative density of $\mathrm{Cnx} 43$, but treatment with PP2 significantly inhibited this increase $(p<0.05)$. Figure 5B shows the effect of those inhibitors on the density of clusters of cells with enhanced Cnx43 label. Monolayers treated with $10 \mu \mathrm{M}$ PP2 had significantly reduced cluster density $(\mathrm{p}<0.05)$ as compared with those treated with ouabain only. Monolayers treated with $25 \mu \mathrm{M}$ PD98059, a substance that impairs the activation of ERK1/2 [49], also show significantly reduced cluster density $(p<0.01)$. Therefore, these results indicate that ouabain modulates the pattern of Cnx43 distribution via c-Src and ERK1/2.

\section{Discussion}

Ouabain, a substance originally identified in plant extracts and used as poison and medication, has received renewed interest since probed to be endogenously present in mammal species including humans. As part of our interest in the effect that ouabain, in a nanomolar range, has on epithelial (MDCK) cells, we evaluated in a previous work, how it influences gap junctional intercellular communication (GJIC) by dye transfer assays and by electrical capacitance measurements [44]. We found that it, triggers an enhanced GJIC response, that is significantly noticeable from 10 minutes after addition of ouabain to the bathing media and reaches a maximum at about one hour, followed by a slow decaying, then a sustained response that last, al least $24 \mathrm{hrs}$. The finding that such enhanced GJIC response is inhibited by PP2 and PD98059, indicates that ouabain activates a signaling cascade that includes activation of c-Src and ERK1/2. Further, in order to determine whether Cnx43 is involved in the GJIC enhancement that ouabain triggers in MDCK cells, we performed silencing assays and found that this procedure effectively impairs it, indicating that $\mathrm{Cnx} 43$ is a determinant player in such response.

Such effect of ouabain on GJIC can be accounted for, either by modulation on the gating properties of connexon units already assembled, or by an increase in the number of connexons available or both. In turn, an increase in the number of connexons may be 


\section{Cellular Physiology Cell Physiol Biochem 2016;39:1329-1338 \\ \begin{tabular}{ll|l} 
DOI: 10.1159/000447837 & $\begin{array}{l}\text { O 2016 The Author(s). Published by S. Karger AG, Basel } \\
\text { www.karger.com/cpb }\end{array}$ \\
\hline
\end{tabular} \\ Ponce et al.: Ouabain Induces Relocation of $\mathrm{Cnx} 43$}

due to promotion of synthesis of new units, or to membrane recruitment of $\mathrm{Cnx} 43$ subunits previously synthesized. However, the fact that its significant response occurs as quickly as 10 min, along with the finding that this response is not impaired by Actinomycin $\mathrm{D}$ that blocks the synthesis of RNA, nor cycloheximide that inhibits the synthesis of proteins, suggest that it is due to the recruitment of subunits already in stock.

In the present work we performed immunofluorescence and immunoblots assays, focusing on $\mathrm{Cnx} 43$ because, as mentioned above, we found that $\mathrm{Cnx} 43$ is a participating subunit type in the ouabain enhanced GJIC. As we show by densitometric analysis of immunoblots, treatment with $10 \mathrm{nM}$ ouabain for 1 hour does no produce a significant increase of $\mathrm{Cnx} 43$ label. This result supports the hypothesis that no synthesis of new $\mathrm{Cnx} 43$ is required at least for the rapid phase of GJIC triggered by ouabain, but rather to the relocation of previously synthesized $\mathrm{Cnx} 43$. However, this conclusion does not exclude, the possibility that synthesis of new subunits occurs in order to maintain GJIC at later times, or that ouabain could additionally modulate the gating of connexons already assembled.

On the other hand, it is interesting that $\mathrm{Cnx} 43$ is expressed in clusters of cells scattered over the monolayer and that ouabain increases the density of such clusters, as well as the average number of cells per cluster. The fact that a significant increase in the density of clusters occurs concomitantly with enhancement of GJIC, along with the finding that such response is impaired by PP2 and PD98059 as in the case of the enhancement of GJIC, suggest that both phenomena are related. It does not mean however that GJIC is a phenomenon exclusively occurring in cells belonging to clusters, because an enhanced GJIC may depend not only on more connexin subunits available at the membrane, but on a gating mechanism regulating the opening of gap junctions. In this regard, it is possible, as already mentioned above, that in addition to promoting relocation to the membrane of $\mathrm{Cnx} 43$ that enhances GJIC, ouabain would modify directly the gating of gap junctions already assembled. This would explain why ouabain enhances GJIC as early as 10 minutes after its addition to the bathing media, although we have not evaluated such possibility yet.

In summary, the present results further support the emerging role of ouabain on the regulation of cellular processes that depend on cell contacts. As we have shown, challenging MDCK cells with $10 \mathrm{nM}$, a concentration within its physiological range triggers a series of changes in the epithelial phenotype, which includes tight junctions, ciliogenesis and gap junctional communication. The effects of hormone ouabain start with the binding of ouabain to the $\alpha$-subunit of $\mathrm{Na}^{+} / \mathrm{K}^{+}$-ATPase, that acts as a receptor $[14,15]$, which in turn, activates a signaling pathway involving c-Src and ERK1/2 [50]. This indicates that the same signaling route mediates all the hormonal effects on cell contacts so far tested. This includes changes of molecular composition of the tight junction [28], to the displacement of $\mathrm{Cnx} 43$ towards the plasma membrane implied in GJIC studied in our previous work [44]. Given that ouabain modulates both tight junctions and apical/basolateral polarity, which are taken as the most specific differentiated features of the epithelial transporting phenotype, we may say that ouabain is a hormone that modulates the expression of the transporting epithelia phenotype. We can even foresee a role of this hormone in clinical medicine, because $90 \%$ of all human deaths involve the collapse of an epithelium. Therefore, further research on hormone ouabain may lead to achievements of biomedical relevance.

\section{Acknowledgments}

We thank Elizabeth del Oso, Yasmín de Lorez, Eduardo Estrada and Eduardo Méndez, for their technical and administrative assistance. Grants: This work was supported by the CONACYT (Mexican Research Council 127329, P221523). Isabel Larre was supported by a postdoctoral research fellowship from Becas Mujeres ICyTDF (2012) and financed by CINVESTAV. 


\title{
Cellular Physiology Cell Physiol Biochem 2016;39:1329-1338 and Biochemistry \begin{tabular}{l|l} 
DOI: 10.1159/000447837 & $\begin{array}{l}\text { (c) } 2016 \text { The Author(s). Published by S. Karger AG, Basel } \\
\text { www.karger.com/cpb }\end{array}$
\end{tabular} Ponce et al.: Ouabain Induces Relocation of $\mathrm{Cnx} 43$
}

\section{Disclosure Statement}

\author{
We declare that we have no conflict of interest
}

\section{References}

3 Buckalew VM: Endogenous digitalis-like factors: an overview of the history.Front Endocrinol (Lausanne) 2015;6:49.

4 Hamlyn JM, Blaustein MP, Bova S, DuCharme DW, Harris DW, Mandel F, Mathews WR, Ludens JH: Identification and characterization of a ouabain-like compound from human plasma. Proc Natl AcadSci U S A 1991;88:6259-6263. Erratum in: Proc Natl Acad Sci U S A 1991;88:9907.

5 Boulanger BR, Lilly MP, Hamlyn JM, Laredo J, Shurtleff D, Gann DS: Ouabain is secreted by the adrenal gland in awake dogs. Am J Physiol 1993;264: E413-E419.

6 Ferrandi M, Manunta P, Balzan S, Hamlyn JM, Bianchi G, Ferrari P: Ouabain-like factor quantification in mammalian tissues and plasma: comparison of two independent assays. Hypertension 1997;30:886-896.

7 Hamlyn JM, Lu ZR, Manunta P, Ludens JH, Kimura K, Shah JR, Laredo J, Hamilton JP, Hamilton MJ, Hamilton BP: Observations on the nature, biosynthesis, secretion and significance of endogenous ouabain. Clin Exp Hypertens 1998;20:523-533.

8 Schoner W: Endogenous cardiac glycosides, a new class of steroid hormones. Eur J Biochem 2002;269:2440-2448.

9 Blaustein MP: Physiological effects of endogenous ouabain: control of intracellular Ca2+ stores and cell responsiveness. Am J Physiol 1993;264:C1367-C1387.

10 Reuter H, Henderson SA, Han T, Ross RS, Goldhaber JI, Philipson KD: The Na+-Ca2+ exchanger is essential for the action of cardiac glycosides. Circ Res 2002;90: 305-308.

11 Contreras RG, Flores-Benitez D, Flores-Maldonado C, Larre I, Shoshani L, Cereijido M: Na+,K+-ATPase and hormone ouabain:new roles for an old enzyme and an old inhibitor. Cell Mol Biol (Noisy-le-grand) 2006;52:31-40.

12 Aperia A: New roles for an old enzyme: Na,K-ATPase emerges as an interesting drug target. J Intern Med 2007;261:44-52.

13 Haas M., Askari A., Xie Z: Involvement of Src and Epidermal Growth Factor Receptor in the Signaltransducing Function of Na+/K+-ATPase. J Biol Chem 2000; 275:27832-27837

14 Xie Z, Cai T: Na+-K+--ATPase-mediated signal transduction: from protein interaction to cellular function. Mol Interv 2003;3:157-168.

15 Aperia A, Akkuratov EE, Fontana JM, Brismar H: Na+-K+-ATPase, a new class of plasma membrane receptors. Am J Physiol Cell Physiol 2016;310:C491-C495.

16 Murata Y, Matsuda T, Tamada K, Hosoi R, Asano S, Takuma K, Tanaka K, Baba A. Ouabain-induced cell proliferation in cultured rat astrocytes. Jpn J Pharmacol 1996;72:347-353.

17 Abramowitz J, Dai C, Hirschi KK, Dmitrieva R, Doris PA, Liu L, Allen JC: Ouabain- and marino bufagenininduced proliferation of human umbilical vein smooth muscle cells and a rat vascular smooth muscle cell line, A7r5. Circulation 2003;16;108:3048-3053.

18 Dmitrieva R, Doris PA: Ouabain is a potent promoter of growth and activator of ERK1/2 in ouabainresistant rat renal epithelial cells. J Biol Chem 2003;25; 278:28160-28166.

19 Trevisi L Visentin B, Cusinato F, Pighin I, Luciani S: Antiapoptotic effect of ouabain on human umbilical vein endothelial cells. Biochem Biophys Res Commun. Biochem Biophys Res Commun 2004;321:716-721.

20 Kulikov A, Eva A, Kirch U, Boldyrev A, Scheiner-Bobis G: Ouabain activates signaling pathways associated with cell death in human neuroblastoma. Biochim Biophys Acta 2007;1768:1691-1702.

21 Olej B, dos Santos NF, Leal L, Rumjanek VM: Ouabain induces apoptosis on PHA-activated lymphocytes. Biosci Rep 1998;18:1-7.

22 Jimenez T, Sánchez G, Blanco G: Activity of the Na,K-ATPase $\alpha 4$ isoform is regulated during sperm capacitation to support sperm motility. J Androl 2012;33:1047-1057.

23 Moreth K, Kuske R, Renner D, Schoner W: Blood pressure in essential hypertension correlates with the concentration of a circulating inhibitor of the sodium pump. Klin Wochenschr 1986;64:239-244.

24 Fedorova OV, Shapiro JI, Bagrov AY: Endogenous cardiotonic steroids and salt-sensitive hypertension. Biochim Biophys Acta 2010;1802:1230-1236.

25 Nesher M, Dvela M, Igbokwe VU, Rosen H, Lichtstein D: Physiological roles of endogenous ouabain in normal rats. Am J Physiol Heart Circ Physiol 2009;297:H2026-H2034. 


\section{Cellular Physiology Cell Physiol Biochem 2016;39:1329-1338

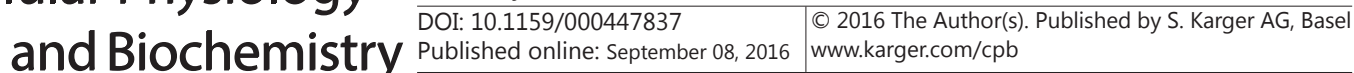 \\ Ponce et al.: Ouabain Induces Relocation of $\mathrm{Cnx} 43$}

26 Li J, Khodus GR, Kruusmägi M, Kamali-Zare P, Liu XL, Eklöf AC, Zelenin S, Brismar H, Aperia A: Ouabain protects against adverse developmental programming of the kidney. Nat Commun 2010;1:1-7.

27 Larre I, Ponce A, Fiorentino R, Shoshani L, Contreras RG, Cereijido M: Contacts and cooperation between cells depend on the hormone ouabain. Proc Natl Acad Sci USA 2006;103:10911-10916.

28 Larre I, Lazaro A, Contreras RG, Balda MS, Matter K, Flores-Maldonado C, Ponce A, Flores-Benitez D, Rincon-Heredia R, Padilla-Benavides T, Castillo A,Shoshani L, Cereijido M: Ouabain modulates epithelial cell tight junction. Proc Natl Acad Sci U S A 2010;107:11387-11392.

29 Cereijido M, Contreras RG, Shoshani L, Flores-Benítez D, Larre I: Tight junction and polarity interaction in the transporting epithelial phenotype. Biochim Biophys Acta 2008;1778:770-793.

30 Larre I, Castillo AM, Flores-Maldonado C, Contreras RG, Galvan I, Munoz-Estrada J, Cereijido M: Ouabain modulates ciliogenesis in epithelial cells. Proc Natl AcadSci USA 2011;108:20591-20596.

31 Evans WH, Martin PE: Gap junctions: structure and function. Mol Membr Biol 2002;19:121-136.

32 Nielsen MS, Axelsen LN, Sorgen PL, Verma V, Delmar M, Holstein-Rathlou NH: Gap junctions. Compr Physiol. 2012;2:1981-2035.

33 Goodenough DA, Goliger JA, Paul DL: Connexins, connexons and intercellular communication. Ann Rev Biochem 1996;65:475-502.

34 Lodish H, Berk A, Matsudaira P, Kaiser C Krieger M, Scott M, Zipursky SL, Darnell J: Molecular Cell Biology. 2004. (5th ed.). New York: W.H. Freeman and Company. pp. 230-1. ISBN 0-7167-4366-3.

35 Willecke K, Eiberger J, Degen J, Eckardt D, Romualdi A, Güldenagel M, Deutsch U, Söhl G: Structural and functional diversity of connexin genes in the mouse and human genome. Biol Chem 2002;383:725-737.

36 Alesutan I, Voelkl J, Stöckigt F, Mia S, Feger M, Primessnig U, Sopjani M, Munoz C, Borst O, Gawaz M, Pieske B, Metzler B, Heinzel F, Schrickel JW, Lang F: AMP-activated protein kinase $\alpha 1$ regulates cardiac gap junction protein connexin 43 and electrical remodeling following pressure overload. Cell Physiol Biochem 2015;35:406-418.

37 Chen M, Liu Y, Yi D, Wei L, Li Y, Zhang L: Tanshinone IIA promotes pulmonary artery smooth muscle cell apoptosis in vitro by inhibiting the JAK2/STAT3 signaling pathway. Cell Physiol Biochem 2014;33:11301138.

38 Zhang A, Han Y, Wang B, Li S, Gan W: Beyond Gap Junction Channel Function: the Expression of Cx43 Contributes to Aldosterone-Induced Mesangial Cell Proliferation via the ERK1/2 and PKC Pathways. Cell Physiol Biochem 2015;36:1210-1222

39 Yang M, Wang B, Li M, Jiang B: Connexin 43 is involved in aldosterone-induced podocyte injury. Cell Physiol Biochem 2014;34:1652-1662.

40 Hervé JC, Pluciennik F, Verrecchia F, Bastide B, Delage B, Joffre M, Délèze J: Influence of the molecular structure of steroids on their ability to interrupt gap junctional communication. J Membr Biol 1996;149:179-187.

41 Watsky MA, Rae JL: Dye coupling in the corneal endothelium: effects of ouabain and extracellular calcium removal. Cell Tissue Res 1992;269:57-63.

42 Martin PE, Hill NS, Kristensen B, Errington RJ, Griffith TM: Ouabain exerts biphasic effects on connexin functionality and expression in vascular smooth muscle cells. Br J Pharmacol 2003;140:1261-1271

43 Matchkov VV, Gustafsson H, Rahman A, Briggs Boedtkjer DM, Gorintin S, Hansen AK, Bouzinova EV, Praetorius HA, Aalkjaer C, Nilsson $\mathrm{H}$ : Interaction between $\mathrm{Na}+\mathrm{K}+-$ pump and $\mathrm{Na}+\mathrm{Ca} 2+$-exchanger modulates intercellular communication. Circ Res. 2007;100:1026-1035.

44 Ponce A, Larre I, Castillo A, García-Villegas R, Romero A, Flores-Maldonado C, Martinez-Rendón J, Contreras RG, Cereijido M: Ouabain increases gap junctional communication in epithelial cells. Cell Physiol Biochem 2014;34:2081-2090.

45 Musil LS, Cunningham BA, Edelman GM, Goodenough DA: Differential phosphorylation of the gap junction protein connexin43 in junctional communication-competent and -deficient cell lines. J Cell Biol 1990;111:2077-2088.

46 Laird DW, Puranam KL, Revel JP: Turnover and phosphorylation dynamics of connexin43 gap junction protein in cultured cardiac myocytes. Biochem J 1991;273:67-72.

47 Solan JL, Fry MD, TenBroek EM, Lampe PD: Connexin43 phosphorylation at S368 is acute during S and G2/M and in response to protein kinase C activation. J Cell Sci 2003;116:2203-2211.

48 Roskoski R: ERK1/2 MAP kinases: structure, function, and regulation. Pharmacol Res 2012;66:105-143.

49 Reiners JJ Jr, Lee JY, Clift RE, Dudley DT, Myrand SP: PD98059 is an equipotent antagonist of the aryl hydrocarbon receptor and inhibitor of mitogen-activated protein kinase kinase. Mol Pharmacol 1998;53:438-445.

50 Zhang L, Zhang Z, Guo H, Wang Y: Na+/K+-Pase-mediated signal transduction and Na+/K+-ATPase regulation. Fundam Clin Pharmacol 2008;22:615-621. 